Research Paper

\title{
TGF $\beta$ upregulates PAR-1 expression and signalling responses in A549 lung adenocarcinoma cells
}

\author{
Natalia Smoktunowicz ${ }^{1}$, Manuela Platé $^{1}$, Alejandro Ortiz Stern ${ }^{1}$, Vanessa

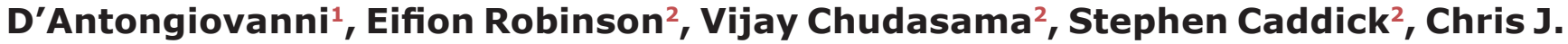 \\ Scotton ${ }^{1}$, Gabor Jarai ${ }^{3}$, Rachel C. Chambers ${ }^{1}$ \\ ${ }^{1}$ Centre for Inflammation and Tissue Repair, UCL Respiratory, University College London, London, UK \\ ${ }^{2}$ Department of Chemistry, University College London, London, UK \\ ${ }^{3}$ Novartis Institutes of Biomedical Research, Horsham, UK \\ Correspondence to: Rachel C. Chambers, email: r.chambers@ucl.ac.uk \\ Keywords: PAR-1, TGF $\beta$, thrombin, cancer \\ Received: February 12, 2016 \\ Accepted: August 06, 2016 \\ Published: August 22, 2016
}

\section{ABSTRACT}

The major high-affinity thrombin receptor, proteinase activated receptor-1 (PAR-1) is expressed at low levels by the normal epithelium but is upregulated in many types of cancer, including lung cancer. The thrombin-PAR-1 signalling axis contributes to the activation of latent TGF $\beta$ in response to tissue injury via an $\beta v \beta 6$ integrin-mediated mechanism. TGF $\beta$ is a pleiotropic cytokine that acts as a tumour suppressor in normal and dysplastic cells but switches into a tumour promoter in advanced tumours. In this study we demonstrate that TGF $\beta$ is a positive regulator of PAR-1 expression in A549 lung adenocarcinoma cells, which in turn increases the sensitivity of these cells to thrombin signalling. We further demonstrate that this effect is Smad3-, ERK1/2- and Sp1-dependent. We also show that TGF $\beta$-mediated PAR-1 upregulation is accompanied by increased expression of integrin $\beta v$ and $\beta 6$ subunits. Finally, TGF $\beta$ pre-stimulation promotes increased migratory potential of A549 to thrombin. These data have important implications for our understanding of the interplay between coagulation and TGF $\beta$ signalling responses in lung cancer.

\section{INTRODUCTION}

Lung cancer is a global health problem with 1.5 million people being diagnosed worldwide every year. This condition accounts for $18 \%$ of all deaths from cancer, which makes it the leading cause of cancer mortality [1]. Cancer patients have a sevenfold increased risk of venous thromboembolism [2] and cancer-related coagulopathy is associated with advanced malignancy and correlates positively with increased mortality rates [3]. Cancer cells constitutively express tissue factor [4], the main initiator of the extrinsic coagulation pathway, and the leaky nature of the tumour vasculature contributes to the accumulation of thrombin in the tumour microenvironment [5]. Thrombin exerts a plethora of cellular effects via the activation of proteinase activated receptor-1 (PAR-1). PAR-1 belongs to a family of four G-protein coupled receptors (PAR 1-4) that are activated via a unique mechanism involving proteolytic cleavage of the $\mathrm{N}$-terminus. This results in the unmasking of a tethered ligand, which then binds intramolecularly to the receptor and initiates cell signalling via the phosphorylation of the associated G-protein complex [6]. PAR-1 forms stable complexes with $\mathrm{G} \alpha_{\mathrm{i} / \mathrm{o}}, \mathrm{G} \alpha_{\mathrm{q} / 11}$, and $\mathrm{G} \alpha_{12 / 13}$ and thereby links to multiple second messenger pathways and influences multiple cellular responses [7].

PAR-1 is expressed at low levels by the normal epithelium but is upregulated in many types of cancer, including lung [5], gastric [8], ovarian [9], prostate [10], melanoma [11], breast [12] and colon cancer [13]. PAR-1 and vascular endothelial growth factor (VEGF) overexpression in lung cancer has been associated with increased metastatic potential [14] and reduced threeyear survival in non-small cell lung cancer [15]. PAR-1 signalling also regulates the expression and leads to the activation of other receptors that contribute to cancer progression. These include platelet-activating factor receptor (PAFR) that causes platelet mobilisation and promotes tumour metastases [16], as well as epidermal growth factor receptor (EGFR) which also promotes tumour invasion [17]. 
PAR-1 has been strongly linked to the integrin mediated activation of latent TGF $\beta$, a pleiotropic cytokine that is a tumour suppressor in normal and dysplastic cells but turns into a tumour promoter in advanced cancer cells [18]. This mode of activation is highly cell-type specific and is mediated via an $\alpha v \beta 6$ integrin-dependent mechanism in epithelial cells [19, 20]; whereas in fibroblasts, this mode of activation is mediated via an $\alpha v \beta 5$ integrin-dependent mechanism [21]. Both modes of activation are dependent on the mechanotransduction of cytoskeletal tension within the cell, which in concert with matrix interactions leads to a change in the conformation of the latent TGF $\beta$ complex and release of active TGF $\beta$ [19, 21-23].

Human tumours overproduce TGF $\beta$, which can lead to the loss of epithelial markers, such as E-cadherin, and epithelial-to-mesenchymal transition (EMT), an event which has been linked to increased tumour cell survival, motility and invasiveness [24]. This is also associated with modulation of tumour cell-stroma interactions through regulation of integrin expression [25], increased production of the matricellular protein, connective tissue growth factor (CTGF) [26] and re-modelling of the extracellular matrix [27]. The $\alpha v \beta 6$ integrin is upregulated in many cancer cells and targeting $\alpha v \beta 6$ leads to reduced TGF $\beta$ activation and cancer cell proliferation [28].

The importance of PAR-1 in mediating TGF $\beta$ activation in vivo is gaining increasing recognition $[19,21]$ but the effect of TGF $\beta$ signalling on PAR-1 expression remains largely unexplored. In this study we investigated the interaction between TGF $\beta$ signalling and PAR-1 expression and functional activity in A549 lung adenocarcinoma cells. We show for the first time that TGF $\beta$ increases PAR-1 gene, protein and cell surface expression and that this in turn results in increased A549 cell responsiveness to subsequent thrombin stimulation. These findings shed important light on the interplay between coagulation and TGF $\beta$ signalling responses and further provide a potential novel mechanistic model by which these pathways may interact to promote lung cancer progression.

\section{RESULTS}

\section{TGF $\beta$ increases PAR-1 expression and renders A549 cells more responsive to thrombin stimulation}

A549 cells express low levels of PAR-1 under baseline conditions. Exposure to TGF $\beta(1 \mathrm{ng} / \mathrm{ml})$ leads to a time-dependent upregulation of $F 2 R /$ PAR-1 mRNA levels from 8 hours onwards with a 4-fold maximal increase at 16 hours (Figure 1A). By 16 hours of TGF $\beta$ exposure, PAR-1 protein levels are also increased and subsequent thrombin-mediated PAR-1 stimulation led to increased ERK phosphorylation at 10 minutes when compared to control cells (Figure 1B). This increase in PAR-1 protein levels occurs with no evidence of E-cadherin loss as determined by immunocytofluorescence at 24 hours (Figure 1C). These data suggest that the increase in PAR1 expression in response to TGF $\beta$ stimulation for 24 hours is not associated with EMT.

Consistent with low protein expression of PAR-1 in A549 cells at baseline, stimulating cells with thrombin and the PAR-1 activating peptide, TFLLR, produced a delayed and modest release of intracellular calcium as determined by monitoring changes in fluorescence following incubation with Fluo4-AM (Figure 2A and 2B). Prestimulation with TGF $\beta$ significantly increased subsequent calcium responses to either thrombin or TFLLR (Figure 2C). These effects were inhibited when thrombin was rendered catalytically inert with hirudin, as well as in the presence of the small molecule PAR-1 antagonist, RWJ58259 (Figure 2D). Moreover, pre-treatment with TGF $\beta$ increased the functional responsiveness of A549 in an agonist concentration-dependent manner (Figure 2E). Under baseline conditions, A549 cells mount a small, albeit significant, increase in intracellular calcium release with increasing concentrations of thrombin. In contrast, pre-exposure to TGF $\beta$ resulted in a 4-fold increase in the magnitude of the calcium response. Taken together these data led us to conclude that TGF $\beta$ increases PAR-1 expression and the subsequent magnitude of the calcium response to thrombin.

\section{TGF $\beta$ regulation of PAR-1 expression is Smad3-, MEK- and SP1-dependent}

We next examined the potential mechanism by which TGF $\beta$ mediates these effects in A549 cells. TGF $\beta$ signals via the formation of a heterotetrameric receptor complex composed of a TGF $\beta$ type 2 receptor dimer with an activin-like kinase (ALK) TGF $\beta$ type 1 receptor dimer; this in turn triggers the Smad signalling pathway by phosphorylating Smad2 and Smad3. In the current study, we show that the effect of TGF $\beta$ pre-treatment on subsequent thrombin-mediated calcium release in A549 cells is inhibited in a concentration-dependent manner in the presence of the ALK5 receptor inhibitor, SB431542, $\left(\mathrm{IC}_{50}=1.7 \mu \mathrm{M}\right)($ Figure $3 \mathrm{~A})$.

The role of Smad2 and Smad3 in TGF $\beta$-mediated PAR-1 upregulation was subsequently investigated using small interfering RNA (siRNA). The silencing of Smad2 and Smad3 expression was validated at the mRNA (Figure 3B and 3C) and protein levels (Figure 3D and 3E). Although Smad2 knockdown was found to exert a small but significant inhibitory effect on the subsequent TGF $\beta$-mediated increase in PAR-1-mediated intracellular calcium release at 48 hours at siRNA concentrations of $10 \mathrm{nM}$ and $30 \mathrm{nM}$, the intracellular calcium flux remained significantly elevated above the unstimulated control cells exposed to thrombin (Figure 3F). In contrast, silencing 
of Smad3 expression significantly reduced the TGF $\beta$ mediated increase in subsequent PAR-1-mediated signalling responses to thrombin in a concentration-dependent manner (Figure 3G). Examination of the kinetics of Smad3 phosphorylation in A549 cells revealed that Smad3 phosphorylation increases from 30 minutes following TGF $\beta$ exposure onwards, peaking at 1 hour with a near 20-fold increase $(p<0.001$ versus control), before returning to control levels by 24 hours (Figure $3 \mathrm{H}$ ). Taken together these data led us to conclude that TGF $\beta$ mediates the increase in PAR-1 expression and functional responses via an ALK5/ Smad3-dependent mechanism.

TGF $\beta$ signalling responses are often dependent on cross-talk with Smad-independent pathways, including ERK, SAPK/JNK, and p38 MAPK pathways. Our studies revealed that the MEK1/MEK2 inhibitor, UO126, inhibited the TGF $\beta$-mediated increase in thrombinstimulated intracellular calcium flux in a concentration-
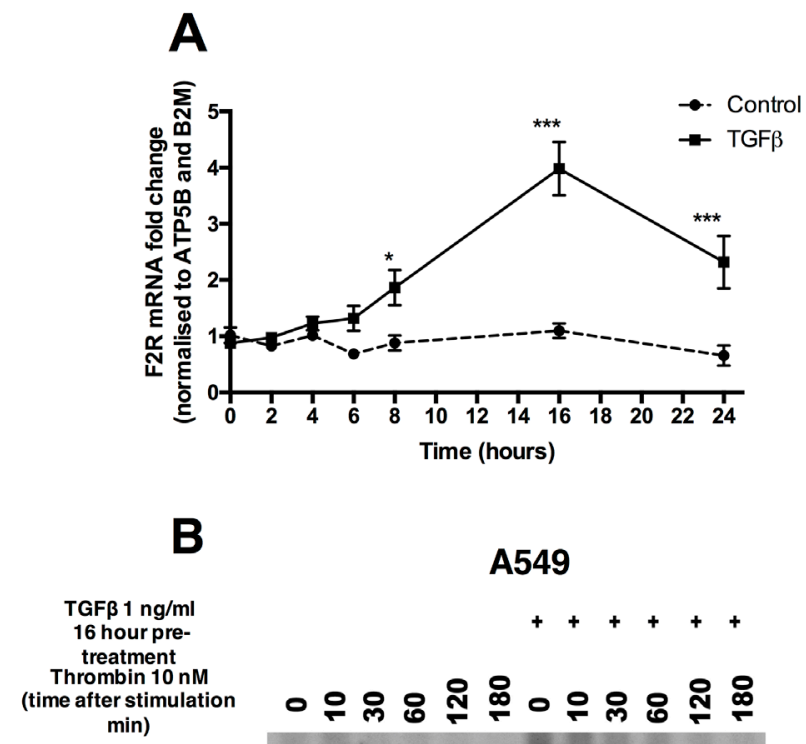

B $\min )$

PAR-1

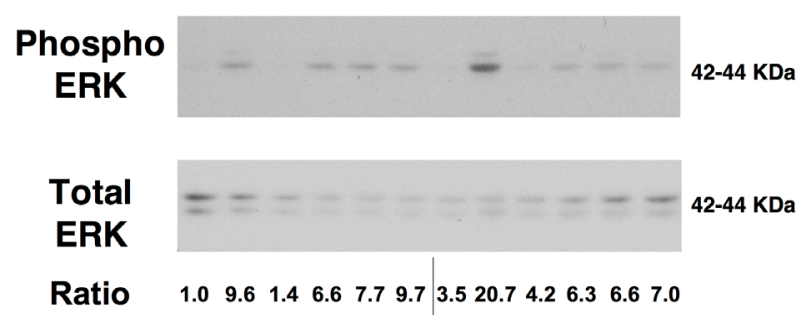

dependent manner with an $\mathrm{IC}_{50}$ of $0.35 \mu \mathrm{M}$ (Figure 4A). In contrast, inhibition of JNK, p38 and Rho kinase did not affect TGF $\beta$-mediated increase in PAR-1 expression and signalling (data not shown). We also confirmed that TGF $\beta$ signalling in A549 cells leads to ERK1/2 phosphorylation, which peaks early at 10 minutes poststimulation (Figure 4B).

We next addressed the question of which transcription factor might be involved downstream of Smad3 and ERK signalling. We focused our studies on the potential role of specificity protein $1(\mathrm{Sp} 1)$ since this transcription factor has been linked to increased $F 2 R$ promoter region binding [11], is known to interact with Smad3 [29] and is also implicated in carcinogenesis [30]. Our studies revealed that mithramycin A and WP631, two inhibitors that specifically displace Sp1 from DNA, were highly effective at blocking the TGF $\beta$-induced increase in PAR-1 mRNA levels (Figure 5A and 5B).

\section{E-cadherin}

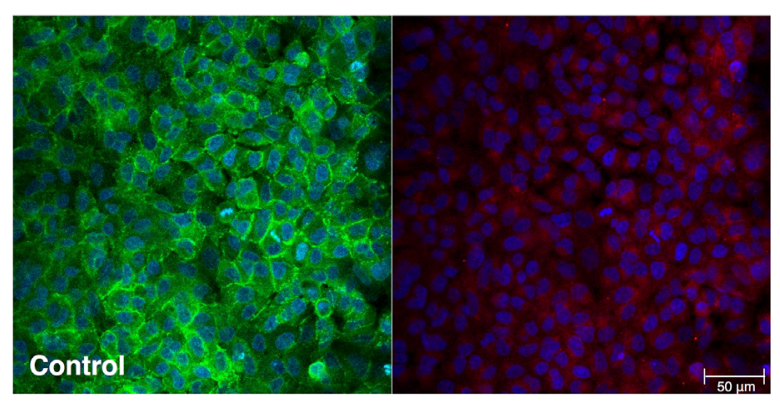

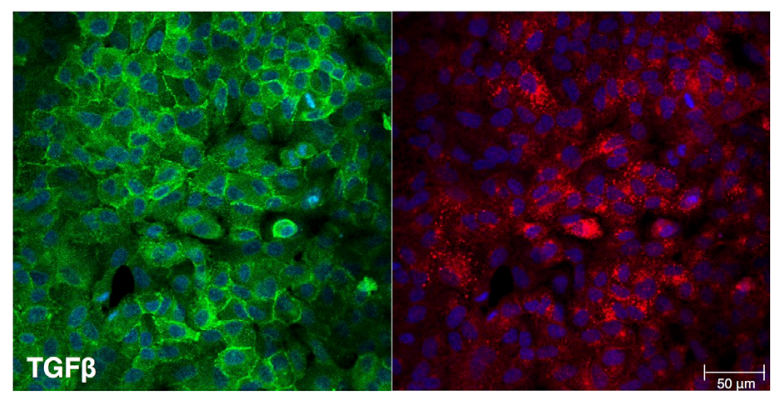

Figure 1: TGF $\beta$ induces the expression of PAR-1 in A549 lung adenocarcinoma cells. Panel A. Human lung adenocarcinoma A549 cells were exposed to TGF $\beta(1 \mathrm{ng} / \mathrm{ml})$ and mRNA collected at indicated times over the course of 24 hours. PAR-1 expression was quantified by real-time qPCR. Each data point represents the mean +/- SEM of 3 replicate wells, statistically analysed by Two-way ANOVA, ${ }^{* *} \mathrm{p}<0.01, * * * \mathrm{p}<0.001$ in comparison to control. Panel B. Western blot analysis of PAR-1 protein expression and phosphorylated and total ERK $1 / 2$ levels following exposure to TGF $\beta(1 \mathrm{ng} / \mathrm{ml})$ for 16 hours and subsequent thrombin $(10 \mathrm{nM})$ stimulation at indicated times. Representative immunoblots with quantitated ratios phosphorylated ERK/total ERK. The PAR-1 predicted molecular weight is $47 \mathrm{kDa}$ but it is detected in most mammalian cells as a broad high molecular weight species due to differential N-linked glycosylation (63). Panel C. Immunocytofluorescence visualisation of E-cadherin (green) and PAR-1 (red) following exposure to TGF $\beta$ ( $1 \mathrm{ng} / \mathrm{ml}$ ) for $24 \mathrm{hours}$. DAPI was used to visualise the nuclei. The top panel shows images for control cells and lower panel show the staining of TGF $\beta$-stimulated cells, x20 original magnification. 


\section{TGF $\beta$ increases integrin expression in A549}

We next examined the potential functional consequences of TGF $\beta$-induced PAR-1 expression. PAR1 activation has been strongly linked to the integrinmediated activation of TGF $\beta$ via the $\alpha v \beta 6$ integrin in epithelial cells [19] and the $\alpha v \beta 5$ integrin in fibroblasts [21]. Examination of these integrin subunit mRNA levels in A549 cells following stimulation with TGF $\beta$ revealed
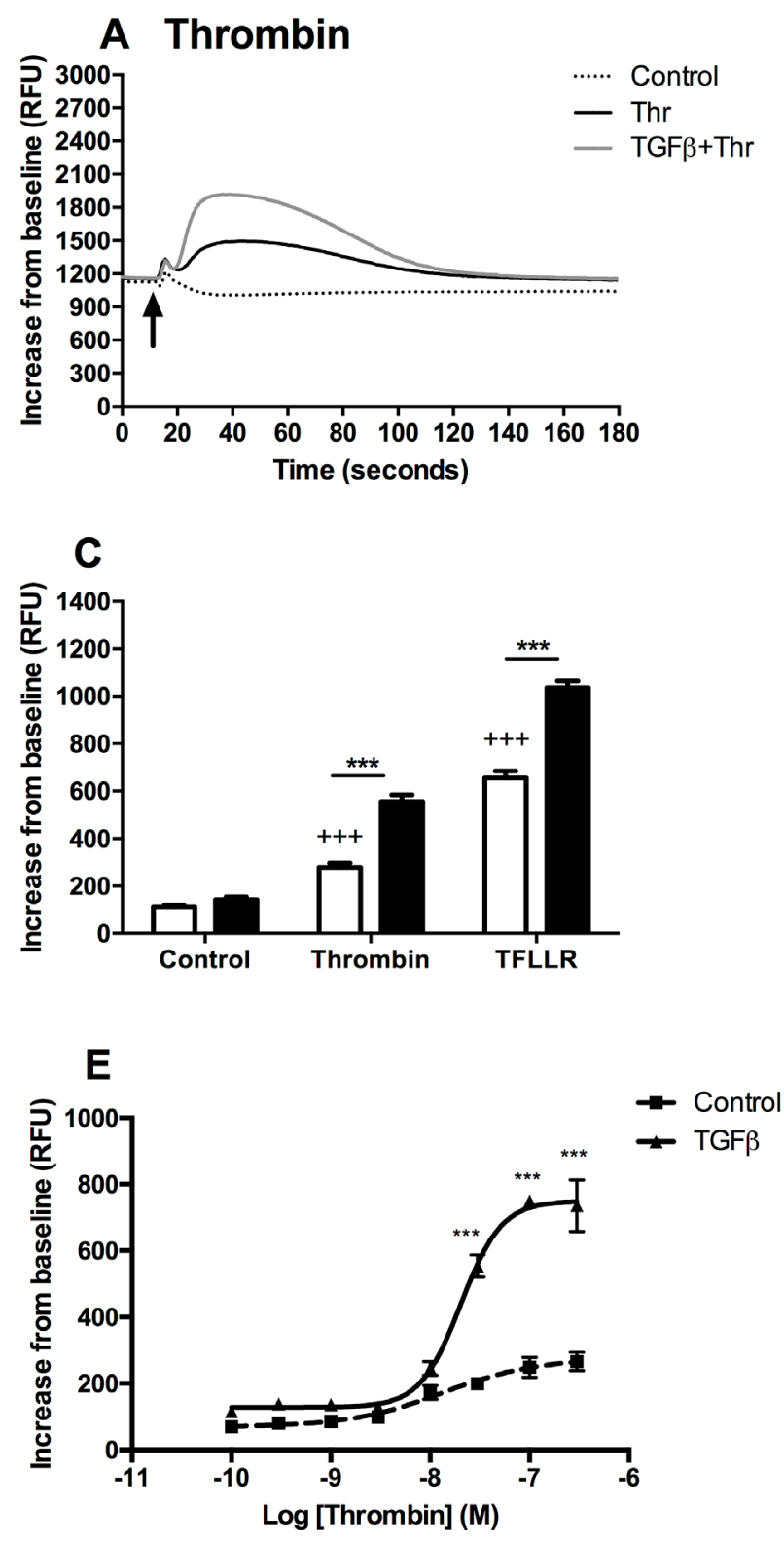

that the $\alpha \mathrm{v}$ and $\beta 6$ subunits were significantly upregulated from 6 and 4 hours onwards, respectively (Figure 6A and $6 \mathrm{~B})$ and that both integrin subunits remained significantly elevated throughout the duration of the experiment (24 hours). Taken together these data demonstrate that TGF $\beta$-induced upregulation of PAR-1 expression is accompanied by increased expression of the major integrin subunits involved in the activation of the latent form of this cytokine.
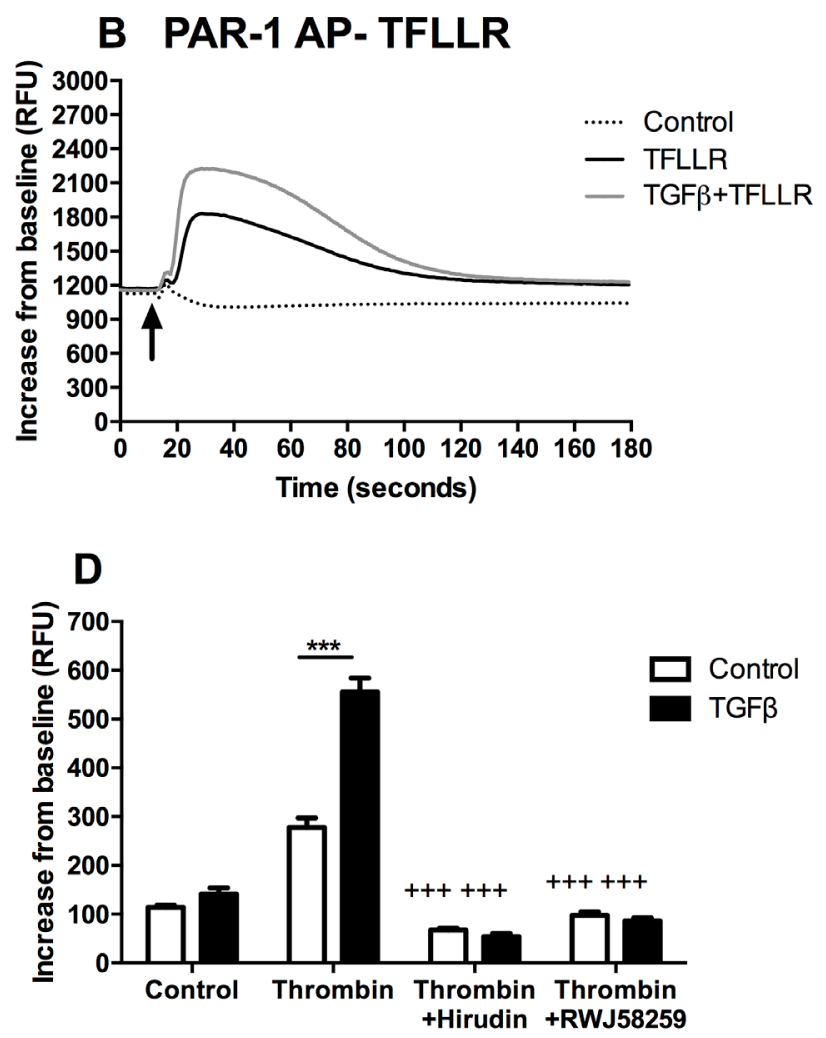

Figure 2: TGF $\beta$-mediated PAR-1 upregulation enhances A549 lung adenocarcinoma cell responsiveness to thrombin signalling. Intracellular calcium release was monitored in A549 cells, pre-treated with TGF $\beta$ ( $1 \mathrm{ng} / \mathrm{ml})$, in response to thrombin (30 nM) and PAR-1 activating peptide, TFLLR (P1 AP, $100 \mu \mathrm{M}$ ). Panel A. Representative traces for thrombin-mediated calcium flux; Panel B. P1 AP TFLLR. Panel C. Analysis of intracellular calcium responses mediated by PAR-1 agonists. Panel D. Thrombin signalling was inhibited directly by pre-incubation with hirudin $(150 \mathrm{nM})$ and by using a PAR-1 antagonist, RWJ58259 $(3 \mu \mathrm{M})$ and calcium flux was analysed. Panel E. Concentration-response curve to thrombin in TGF $\beta$-pre-treated (solid line) and control (dotted line) A549 lung adenocarcinoma cells. Each data point represents the mean +/- SEM of 3-4 replicate wells from at least two independent experiments. Two-way ANOVA was performed for statistical analysis, ${ }^{* * *} \mathrm{p}<0.001$ comparison between control and TGF $\beta$-pre-treated cells; $+++\mathrm{p}<0.001$ comparison between treatments. 


\section{TGF $\beta$ increases A549 migratory potential via PAR-1}

We further examined A549 cell motility in response to PAR-1 activation following TGF $\beta$ pretreatment. Identical scratch wounds were introduced in confluent A549 cell monolayers. Cell migration was monitored over 24 hours and reported as wound confluence and cell density (Figure 7A and 7B). We observed that TGF $\beta$ and thrombin independently increased the rate of cell migration in A549 cells when compared with untreated cells at 24 hours. Subsequently, cells exposed to TGF $\beta$ and then stimulated with thrombin showed the highest rate of migration in this model. Inhibition of PAR-1 signalling with RWJ58259 abrogated this response. We further investigated the dynamics of this response by investigating the time-course of A549 migration in the wound assay (Figure 7C and 7D). Data collected at 6,12 and 18 hours confirmed that cells exposed to TGF $\beta$ have a faster migration rate compared with control stimulated cells throughout the experiment. Furthermore, RWJ58259 inhibited the thrombin-mediated migration at 12 and 18 -hour time points $(\mathrm{p}<0.01)$ while the TGF $\beta$-thrombinRWJ58259 treated cells migrated at a rate which was similar to TGF $\beta$ alone stimulated cells. These data led us to conclude that the additive effect of these two independent pathways increases A549 motility.
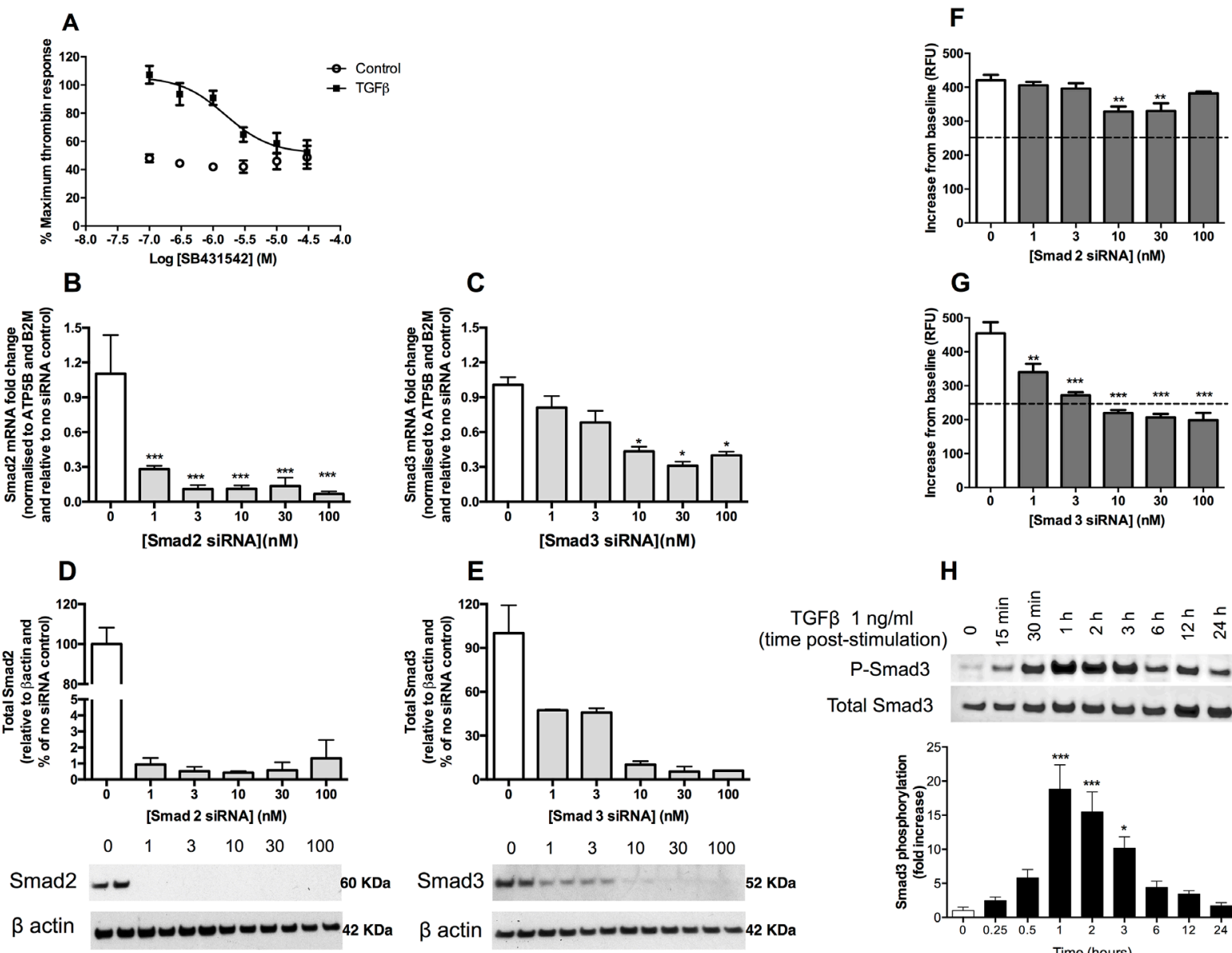

H
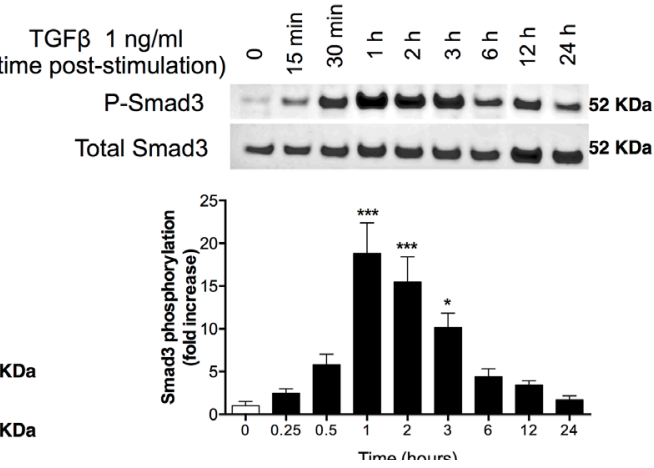

Figure 3: TGFß upregulates PAR-1 expression in A549 lung adenocarcinoma cells via an ALK5-Smad3-dependent mechanism. Panel A. Dose-inhibition curve in A549 cells exposed to TGF $\beta(1 \mathrm{ng} / \mathrm{ml})$ with varying concentrations of TGF $\beta$ receptor (ALK5) inhibitor, SB431542, for 24 hours and then stimulated with thrombin. Panels B and C. Smad2 and Smad3 siRNA knockdown measured by mRNA (real-time qPCR, each data point represents the mean $+/$ - SEM of 3 replicate wells; one-way ANOVA, *p $<0.05$, ${ }^{* * *}$ p $<0.001$, relative to non-transfected control) and Panels D and E. Smad2 and Smad3 protein knockdown 48 hours post-transfection (Western blot, semi-quantitative densitometry analysis of the total protein of interest relative to the $\beta$-actin loading control, each data point represents the mean +/-SEM of 2 replicates as shown on the blots). Panels F and G. Intracellular calcium release was measured in A549 cells treated with varying concentrations of Smad2 and Smad3 siRNA, respectively, for 48 hours prior to stimulation with TGF $\beta(1 \mathrm{ng} / \mathrm{ml})$ for 24 hours. Cells were incubated with Fluo-4AM calcium binding dye for one hour before being exposed to thrombin $(30 \mathrm{nM})$. Each data point represents the mean +/- SEM of 3-4 replicate wells; Two-way ANOVA, ***p $<0.001$ comparison of control and TGF $\beta$ pre-treated cells. Panel H. A549 cells were incubated with or without TGF $(1 \mathrm{ng} / \mathrm{ml})$ for up to 24 hours. Representative immunoblots of total and phosphorylated Smad3 and quantification of relative intensity of pSmad3 immunoreactive bands by densitometry. Data shown are mean \pm SEM of 3 independent experiments and expressed as fold increase over control cells, analysed by one-way ANOVA, ${ }^{*} \mathrm{p}<0.05,{ }^{* * *}<00.001$. 


\section{DISCUSSION}

The PAR receptors act as sensors of extracellular proteinase gradients and allow cells to react and respond to proteolytic changes within their microenvironments [12]. PAR-1, the prototypic member of the PAR family, has been identified as an oncogene and has been reported to promote cancer invasion and metastasis in the context of multiple cancers, including breast, colon, lung, pancreatic and prostate cancer as well as melanoma [14, 31-35]. Furthermore, PAR-1 expression levels positively correlate with the degree of cancer invasiveness [33]. TGF $\beta$ signalling similarly regulates a plethora of cell responses, including cell growth, differentiation, apoptosis, motility, invasion, ECM production, angiogenesis, and immune responses [36]. In the setting of cancer, TGF $\beta$ plays a dichotomous role in that it acts as a tumour suppressor in early tumorigenesis and as an oncogene in the later phases of tumour progression [37].

The aim of the present study was to explore the interplay between PAR-1 and TGF $\beta$ signalling responses in the context of lung cancer. Using A549 adenocarcinoma cells, we show for the first time that TGF $\beta$ increases the expression of PAR-1 and thereby leads to increased cellular responsiveness to thrombin. Thrombin is regarded as a key mediator in cancer growth and metastatic spread, via both the formation of fibrin and via its plethora of PAR-1 mediated cellular responses, including effects on DNA synthesis and cell proliferation, platelet activation, vascular permeability, cell migration, and induction of pro-angiogenic and pro-metastatic factors, such as VEGF (Reviewed in [38]).
The TGF $\beta$ receptors are constitutively expressed and form heterotetrameric TRRII-ALK5 ligandreceptor complexes upon ligand binding. This leads to phosphorylation of specific serine and threonine residues and activation of canonical TGF $\beta$ signalling via the phosphorylation of Smad2 and Smad3 that, upon binding to co-factor Smad4, translocate to the nucleus and influence target gene expression. In the present study, using ALK5 small molecule inhibition and siRNA knockdown of Smad2 and Smad3, we demonstrate that the upregulation of PAR-1 expression is both ALK-5 and Smad3-dependent in A549 adenocarcinoma cells. Interestingly, the TGF $\beta$-Smad3 signalling pathway has previously been shown to promote cancer cell survival and metastasis [39].

TGF $\beta$ bound to T $\beta$ RII-ALK 5 complexes also leads to phosphorylation of tyrosine residues and the recruitment of adaptor molecules involved in the activation of MAPK kinase (ERK, JNK and p38) signalling [40]. TGFßdependent ERK signalling has been linked to EMT in cancer cells [41] and genetic profiling of TGF $\beta$-mediated EMT revealed that ERK participates in the regulation of the expression of cell-matrix adhesion and motility genes [42]. In the present study, we show that the TGF $\beta$-mediated increase in PAR-1 functional responses (calcium signalling) is also MEK-dependent; with no role identified for JNK or p38 signalling. It has previously been reported that at least 48 hours of prolonged exposure to TGF $\beta$ is necessary for a complete loss of epithelial marker expression and evidence of mesenchymal marker expression in cancer cells [43]. PAR-1 expression is low in lung epithelial cells; whereas fibroblasts express PAR-1
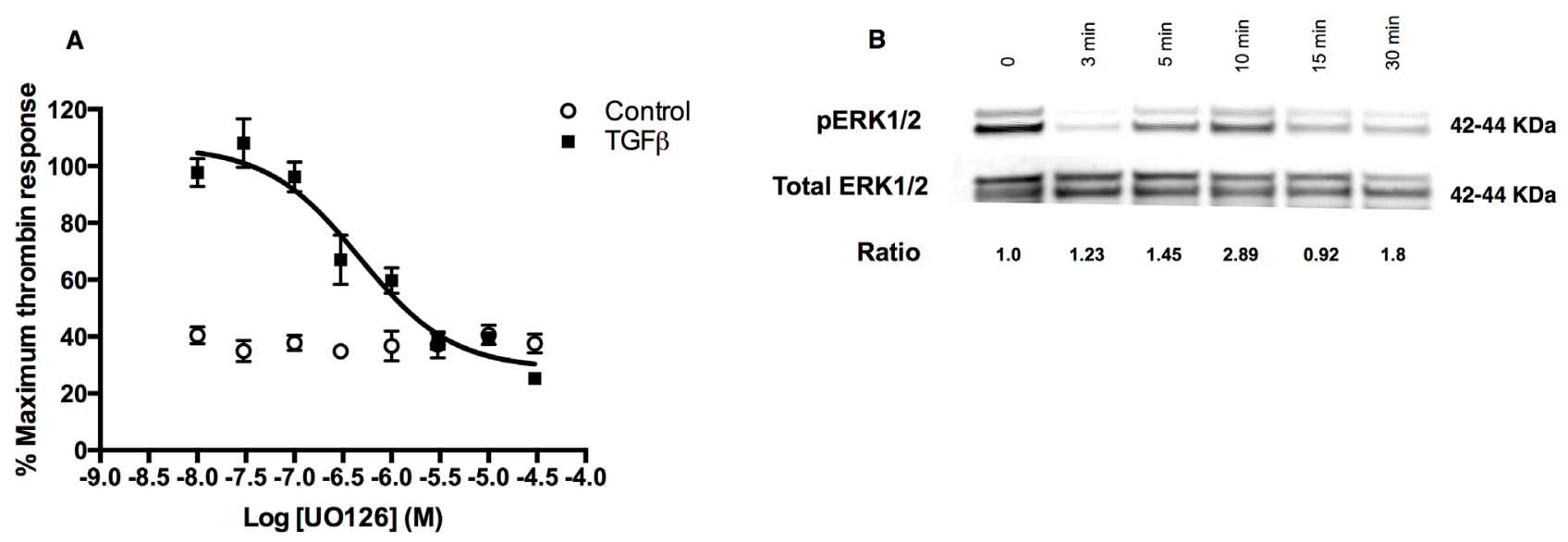

Figure 4: TGFß-ERK1/2 signalling is also involved in regulation of PAR-1 expression in A549 cells. Panel A. Doseinhibition curve in A549 cells exposed to TGF $\beta(1 \mathrm{ng} / \mathrm{ml})$ with varying concentrations of MEK1/2 inhibitor, UO126, for 24 hours and then stimulated with thrombin $(30 \mathrm{nM})$. Each data point represents the mean $+/-$ SEM of 3-4 replicate wells. Panel B. Representative immunoblot of ERK1/2 phosphorylation in A549 cells incubated with TGF $\beta(1 \mathrm{ng} / \mathrm{ml})$ for up to 30 minutes with corresponding pERK/total ERK ratios derived from densitometry analysis. 


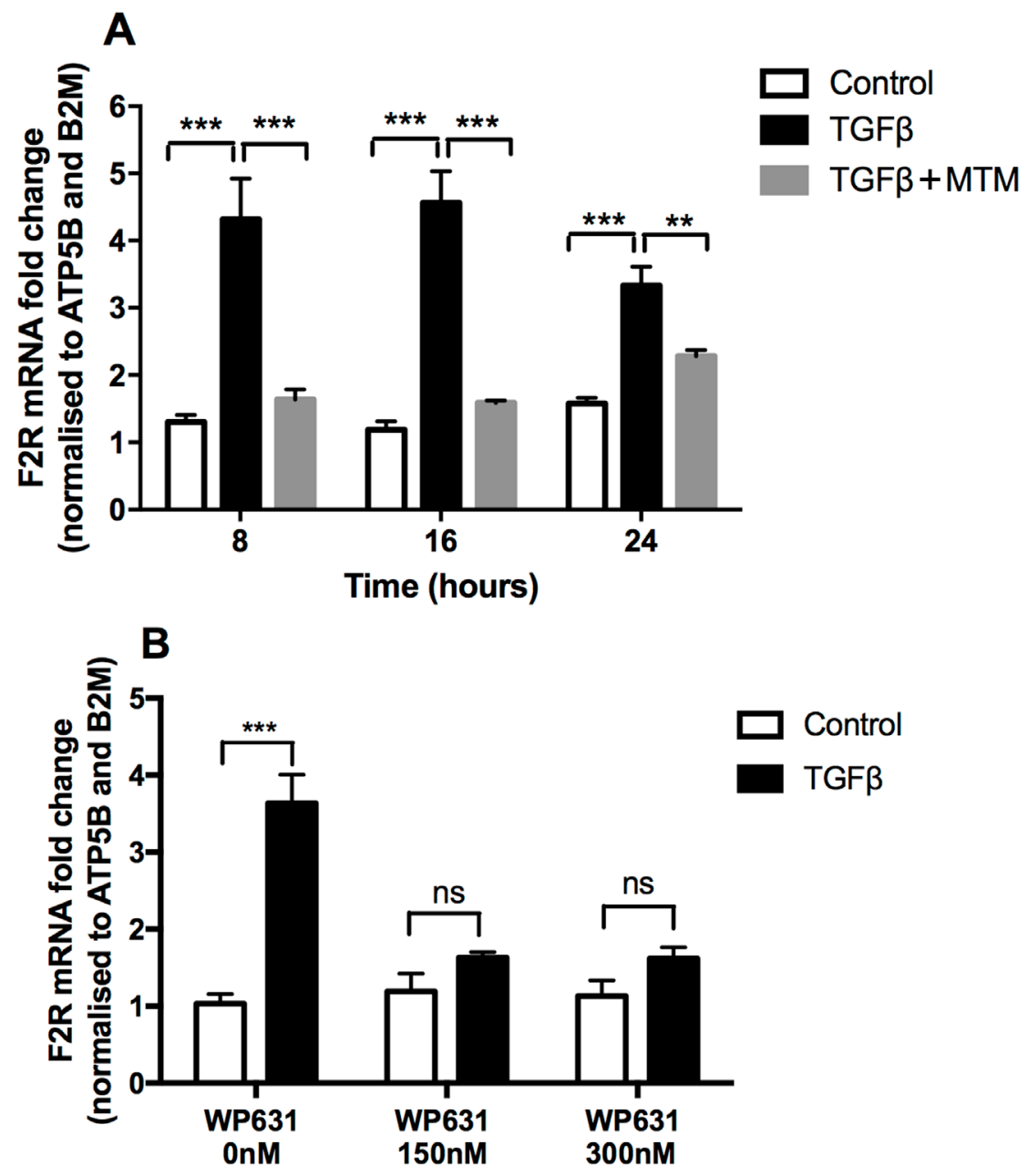

Figure 5: TGF $\beta$-mediated PAR-1 upregulation is blocked by Sp1 inhibitors. A549 lung adenocarcinoma cells were incubated with or without TGF $\beta(1 \mathrm{ng} / \mathrm{ml})$ for 24 hours and in the presence of the Sp1 inhibitors. Panel A. Mithramycin A (10 $\mu$ M) for 8, 16 and 24 hours, Panel B. WP631 for 16 hours at the concentration $150 \mathrm{nM}$ and $300 \mathrm{nM}$. PAR-1 expression was quantified by real-time qPCR. Each data point represents the mean $+/$ - SEM of 3 replicate wells, analysed by Two-way ANOVA, $* * p<0.01, * * * p<0.001$ in comparison to vehicle control.
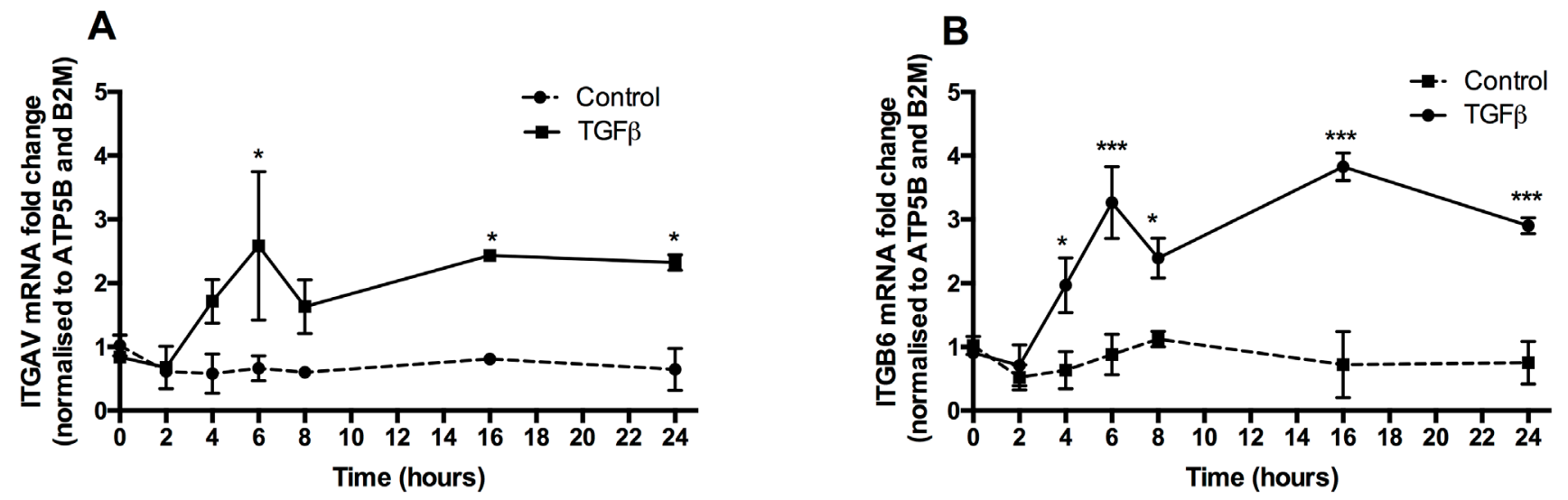

Figure 6: TGF $\beta$ promotes $\boldsymbol{\alpha v}$ and $\boldsymbol{\beta} 6$ integrin sub-unit gene expression. Panels A and B. A549 lung adenocarcinoma cells were incubated with or without TGF $\beta(1 \mathrm{ng} / \mathrm{ml})$ for 24 hours. The mRNA was collected at indicated times in the course of 24 hours. Integrin subunits $\alpha \mathrm{v}$ and $\beta 6$ expression was quantified by real-time qPCR. Each data point represents the mean $+/-$ SEM of 3 replicate wells, analysed by Two-way ANOVA, $* * p<0.01, * * * p<0.001$ in comparison to control. 
abundantly $[44,45]$. In our study we note that the increase in PAR-1 expression in A549 cells occurs within 24 hours of TGF $\beta$ stimulation when E-cadherin is still highly expressed, indicating that acquisition of PAR-1 expression precedes the EMT process. Interestingly, gastric cancer cells [46] and A549 cells [47] have been shown to undergo thrombin-induced EMT via PAR-1 and ERK 1/2 activation, albeit over longer period of time ( 72 hours). In our study, we show that increased PAR-1 expression following exposure to TGF $\beta$ is also associated with increased ERK phosphorylation in response to thrombin stimulation. Taken together our findings combined with existing data in the literature point to the possibility that the early TGF $\beta$-mediated increase in PAR-1 expression and subsequent increased responsiveness to thrombin could be a part of the EMT process.

In terms of the transcriptional regulation of PAR1 expression, the transcription factors involved remain to be fully characterized but appear to be highly cell- specific. Moreover, PAR-1 expression is differently regulated during homeostasis and in disease, and displays both cell- and tissue-specific variations. The $F 2 R$ gene promoter has been characterised and presents, among many transcription factor binding elements, two AP-2-Sp1 complexes at its proximal 3' end. Overall, these complexes contain 3 AP-2 binding sites and 7 Sp1 binding sites [48]. In human melanoma cells, AP-2 has been shown to repress PAR-1 expression and compete with the positive regulator $\mathrm{Sp} 1$. The loss of AP-2 and predominant binding of Sp1 is linked to the overexpression of PAR-1 and the metastatic phenotype of these cells [49]. This evidence together with the reported observation that Smad3 can form transcriptional complexes with $\mathrm{Sp} 1$ to regulate gene expression [50], led us to focus our investigation on Sp1 as a candidate transcription factor in mediating TGF $\beta$ induced PAR-1 upregulation in A549 adenocarcinoma cells. These studies revealed that the widely used Sp1 inhibitor, mithramycin $\mathrm{A}$, that binds to $\mathrm{GC}$ rich DNA

\section{A}
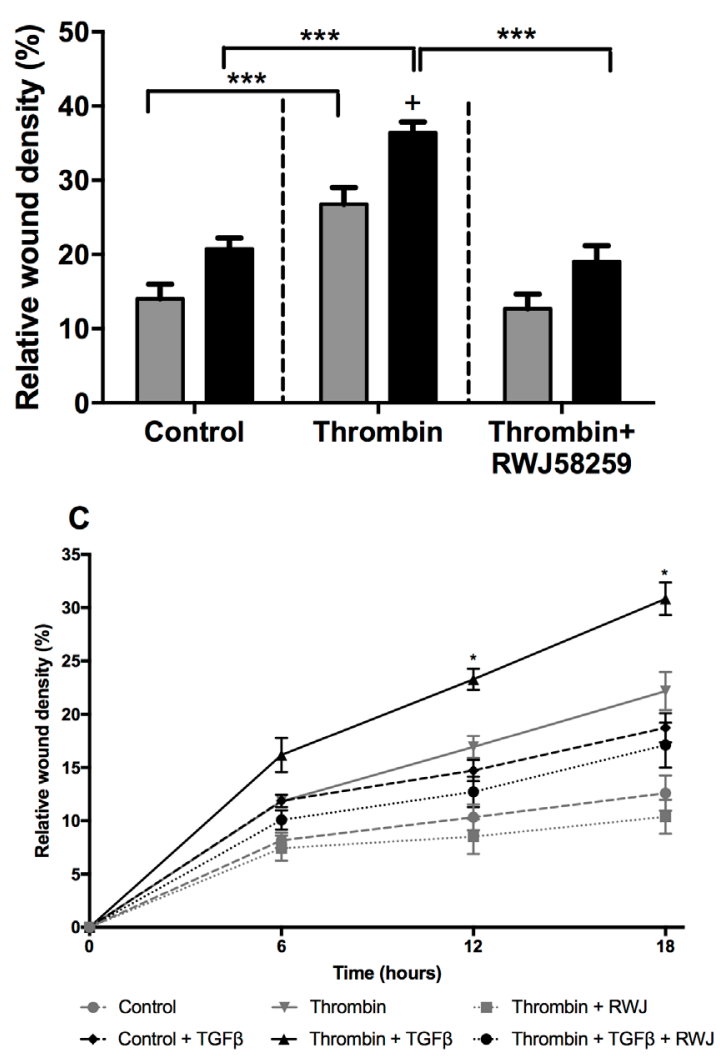

B
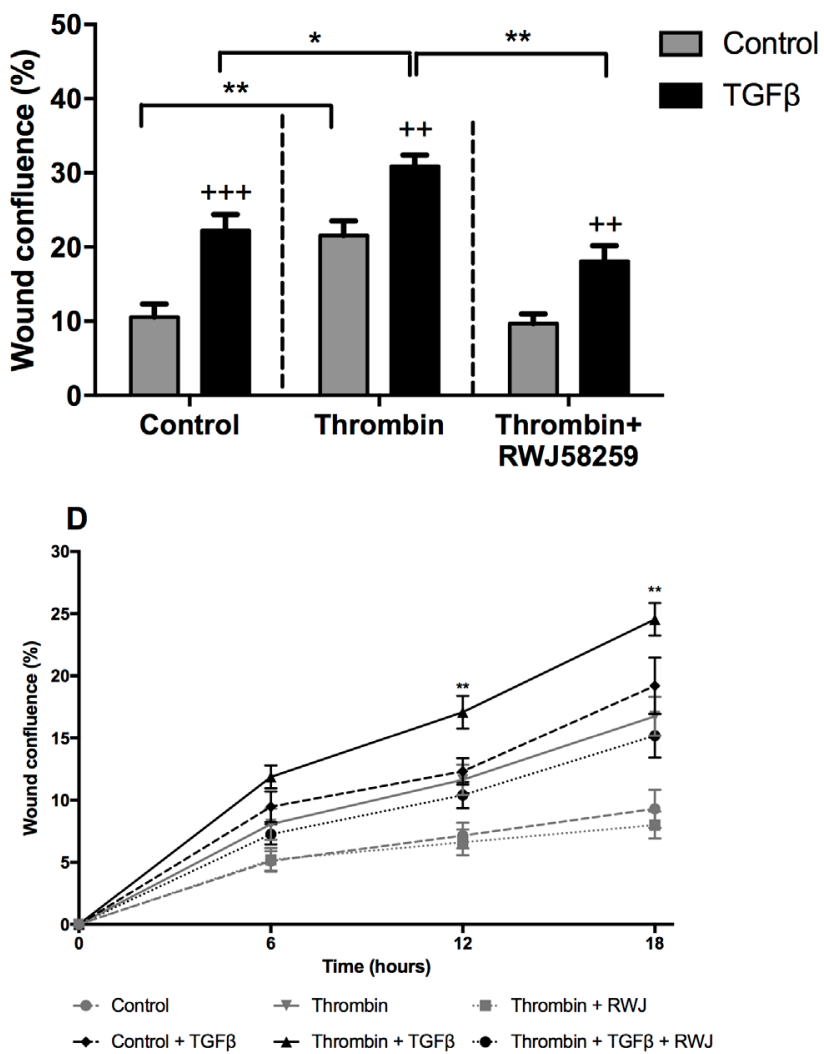

Figure 7: The effect of TGF $\beta$ treatment on A549 lung adenocarcinoma cells migration. A549 cells were incubated with or without TGF $\beta(1 \mathrm{ng} / \mathrm{ml})$ for 24 hours and pre-treated with PAR-1 inhibitor, RWJ58259 (3 $\mu \mathrm{M})$ for 30 minutes. Homogenous scratch wounds were introduced using WoundMaker (Essen Bioscience, UK) and cells immediately stimulated with thrombin (10 nM). Wound closure was monitored for up to 24 hours and data analysed using Incucyte Zoom Live Cell Imaging System (Essen Bioscience, UK). Panel A. Difference in wound cell density and Panel B. Wound confluence at 24 hours. Panel C and D. Time-course of wound closure with data collected at 6,12 and 18 hours with control and control + TGF $\beta$ denoted by dashed lines, thrombin and thrombin + TGF $\beta$ denoted by continuous lines and thrombin + RWJ58259 and thrombin + TGF $\beta+$ RWJ58259 denoted by dotted lines. Data are plotted as mean +/- SEM of $\mathrm{n}=5$ replicate wells from 2 independent experiments; Two-way ANOVA, $+\mathrm{p}<0.05,++\mathrm{p}<0.01,+++\mathrm{p}<0.001$ in comparison to control, $* \mathrm{p}<0.05, * * \mathrm{p}<0.01, * * * \mathrm{p}<0.001$ comparison between stimulations. 
sequences [51-56], completely blocked the TGF $\beta$ induced increase in PAR-1 mRNA levels. We further confirmed the role of Sp1 in TGF $\beta$-mediated PAR-1 regulation by using a second $\mathrm{Sp} 1$ inhibitor, the bisintercalating anthracycline, WP631, which has high specificity and binding affinity for Sp1-DNA binding sites at concentrations within the nanomolar range [57, 58].

We next sought to determine whether TGF $\beta$ induced PAR-1 expression is accompanied by an increase in $\alpha v \beta 6$ integrin expression. This integrin is expressed at low levels in normal epithelium but is known to be upregulated in response to tissue injury [19] and cancer [59]. Moreover, blocking $\alpha v \beta 6$ integrin and TGF $\beta$ signalling has been shown to reduce tumour invasiveness [28]. In the present study we found that the increase in PAR-1 expression following TGF $\beta$ stimulation in A549 cells is accompanied by a concomitant upregulation of $\alpha \mathrm{V}$ and $\beta 6$ integrin subunit expression. It is important to note that the upregulation of the expression of these three genes did not require PAR-1 activation so that the upregulation of integrin expression is TGF $\beta$ dependent but PAR-1independent. It is tempting to speculate that the interplay of this TGF $\beta$-PAR-1 axis might potentially lead to a feedforward mechanism, which could drive the perpetuation of $\alpha v \beta 6$-mediated TGF $\beta$ activation and signalling in the presence of uncontrolled coagulation.

Finally, in order to further investigate the functional consequences of increased PAR-1 expression in response to TGF $\beta$ exposure in A549 cells, we performed a cell motility assay and show that there was a significant, additive effect on cell migration when TGF $\beta$-pre-treated cells were stimulated by thrombin. These additive effects were abolished in the presence of the PAR-1 inhibitor. Although there is existing evidence that PAR-1 and TGF $\beta$ independently promote cancer cell motility and migration $[12,18,60]$, to the best of our knowledge, this represents the first report of a potential novel mechanism by which the TGF $\beta$ and PAR-1 signalling pathways may converge to promote cancer cell function.

\section{Conclusion and therapeutic implications}

In conclusion, our data show for the first time that TGF $\beta$ is a potent inducer of PAR-1 expression in lung adenocarcinoma cells. These effects are mediated via canonical TGF $\beta$ signalling with ALK5 and Smad3 acting in cooperation with an ERK-dependent mechanism and Sp1-dependent gene transcription. The upregulation of PAR-1 is accompanied by increased $\alpha \mathrm{v}$ and $\beta 6$ integrin subunit expression providing a potential mechanism for prolonged TGF $\beta$ activation in the pro-coagulant environment. These findings provide a scenario for the convergence of TGF $\beta$ and coagulation signalling to promote cancer cell function and migration. Future studies with an orally available, potent, PAR-1 antagonist (SCH530348/vorapaxar; trade name, Zontivity) which was recently approved by the U.S. Food and Drug Administration to reduce the risk of heart attacks and stroke in high-risk patients [61], as well as $\alpha v \beta 6$ integrin blocking agents, which are currently in clinical development [62], may offer therapeutic approaches for lung adenocarcinoma and potentially other cancers.

\section{MATERIALS AND METHODS}

\section{Reagents and inhibitors}

Commercially-available A549 cells were characterised and sourced from ATCC (LGC Standards, UK). Human $\alpha$-thrombin was purchased from Enzyme Research Laboratories, UK. Transforming growth factor $\beta-1$ (TGF $\beta-1)$ was purchased from R\&D Biosystems, UK. PAR-1 agonist peptide TFLLR-NH $\mathrm{N}_{2}$ was purchased from Bachem AG, Switzerland. Hirudin was purchased from Sigma, UK. MEK inhibitor, UO126, and ALK5 inhibitor, SB431542 were purchased from Calbiochem, UK. PAR-1 ATAP2 detection antibody was purchased from Santa Cruz Biotechnology, USA. Total Smad2 and Smad3, and phosphorylated Smad2 and Smad3, ERK and phosphorylation ERK antibodies were purchased from Cell Signalling Technologies, USA. PAR-1 inhibitor, RWJ58259, was synthesised in-house by the Department of Chemistry, UCL. Mithramycin A was purchased from VWR International, UK and WP631 was purchased from Insight Biotechnology, UK.

\section{RT-PCR and real-time RT-PCR analysis}

Total RNA from cell culture lysates was isolated with TRIzol reagent as per manufacturer's protocol (Invitrogen, UK). Contaminating genomic DNA was removed using the Ambion DNAfree kit and cDNA was prepared by reverse-transcription (RT) using the qScript cDNA SuperMix ${ }^{\circledR}$ kit (Quanta Biosciences, USA) following the manufacturer's instructions. Real time RT-PCR was conducted using the Platinum SYBR Green qPCR SuperMix UDG (Invitrogen, UK) with $\sim 1 \mathrm{ng}$ of cDNA, and in-house designed forward and reverse primers (Table 1) each at a final concentration of $800 \mathrm{nM}$, on a Mastercycler EP Realplex (Eppendorf, Germany) at primer annealing temperature of $60^{\circ} \mathrm{C}$. The GeNorm algorithm was applied to produce the optimal normalisation factor and two housekeeping genes, ATP synthase, $\mathrm{H}^{+}$transporting, mitochondrial $\mathrm{F} 1$ complex, beta polypeptide (ATP5B) and beta-2-microglobulin (B2M), showed the highest reference target stability for human cells. Housekeeping primer, Smad2 and Smad3 primer mixes were purchased from PrimerDesign (Southampton, UK). To examine the quantitative differences in target mRNA expression in each sample, $\mathrm{Cp}$ values were determined from the linear region of the logarithmic amplification plot. The fold change was subsequently 
Table 1: Primers

\begin{tabular}{lcc}
\hline Gene & Forward sequence & Reverse sequence \\
\hline hPAR-1 & AGGCCAGAATCAAAAGCAAC & TCATCCTCCCAAAATGGTTC \\
hITGAV & TCTGTGCCGCGCCTTCAACC & AACATCCGGGAAGACGCGCTG \\
hITGB6 & AAGTTGAGACCAGGTGGTGCGC & CCATGGAGGCGGAGAGGTCCAT \\
\hline
\end{tabular}

calculated using the standard $2^{-\Delta \Delta \mathrm{Cp}}$ approach. Statistical analysis was performed using the $\Delta \mathrm{Cp}$ values.

\section{Transfection with siRNA}

SMARTpool ONTARGETplus Human siRNA targeting Smad2 and Smad3 and the ONTARGETplus Nontargeting Pool (Thermo Scientific, UK) were reconstituted to $20 \mu \mathrm{M}$ stock in RNA buffer. A range of siRNA concentrations (100 nM, $30 \mathrm{nM}, 10 \mathrm{nM}, 3 \mathrm{nM}$, $1 \mathrm{nM}$ ) was tested to optimise the conditions and combined with Interferin transfection reagent (Polypus, UK) as per the manufacturer's protocol. Following reverse transfection protocol, A549 cells were combined with the transfection mix and immediately seeded. Cells were then incubated for 48 hours, after which the medium was removed and the samples collected for mRNA and protein analysis or replaced with serum-free medium for another 24 hours before cells were stimulated.

\section{Western blot}

Cells were seeded in 24-well plates and following appropriate treatment, cells were washed with cold PBS and lysed in $100 \mu \mathrm{l}$ of phosphosafe extraction buffer (Merck Chemicals, UK) supplemented with a complete protease inhibitor cocktail. BCA assay was used to measure protein concentration as per the manufacturer's protocol and the sample mixed with Laemmli buffer containing DTT. Following protein denaturation, the samples were loaded onto a pre-cast 4-12\% polyacrylamide gel (Bolt Bis-Tris Plus gels, Novex, Life Technologies, UK). A Plus Prestained Protein Ladder (Fermentas, UK) with $10-250 \mathrm{kDa}$ detection range was run in a separate lane to identify the molecular weights of individual proteins. Electrophoresis was performed at $165 \mathrm{~V}$ for 35 minutes. Dry protein transfer onto polyvinyldene difluoride (PVDF) membrane was performed using the iBlot Gel Transfer Device (Novex, Life Technologies, UK) at $20 \mathrm{~V}$ for 7 minutes. The membrane was subsequently incubated in blocking buffer, followed by primary detection antibodies for the protein of interest and finally with a specific horseradish peroxidise (HRP)-linked secondary antibody. The membrane was developed by enhanced chemiluminescence (ECL) following the manufacturer's instructions (GE Healthcare, UK). Immunoreactive protein bands were visualised by exposing the membrane to autoradiography film developer (Kodak, UK) and the exposure time adjusted to the strength of the signal.

\section{Intracellular calcium measurement}

Cells were seeded 48 hours prior to the experiment in black 96-well plates with a clear bottom. On the day of the assay 1 vial of Fluo 4-AM dye was resuspended in $10 \mathrm{ml}$ of HBSS/Hepes assay buffer without calcium or magnesium (Invitrogen, UK). Cells were incubated with the dye, $100 \mu \mathrm{l} /$ well, for 30 minutes at $37^{\circ} \mathrm{C}$ and calibrated for another 30 minutes at room temperature. The PAR-1 antagonists used in this study were added and incubated with the dye for an hour prior to the experiment. PAR-1 agonists were prepared at $3 \mathrm{x}$ final desired concentration in assay buffer and $50 \mu \mathrm{l}$ per well of appropriate compound was added to a 96-well agonist plate. Changes in the intracellular $\mathrm{Ca}^{2+}$ were monitored using a fluorescent image plate reader FLIPR Tetra (Molecular Devices, USA) and the results displayed and analysed using the ScreenWorks software. The device is fitted with a standard ECCM camera that records the fluorescent signal produced by light-emitting diodes (LED) that excites the Fluo-4AM dye at wavelength of $494 \mathrm{~nm}$ with emission at $516 \mathrm{~nm}$. The fluorescence was monitored for 10 seconds before the agonists were simultaneously dispensed to the 96-well plate by the overhead pipettor. Readings were recorded every second for the first 60 seconds and every 6 seconds for the next 120 seconds. The change in intracellular calcium $\left[\mathrm{Ca}^{2+}\right]$ was quantified as an increase in relative fluorescence units (RFUs). The difference between maximum and minimum RFU was used to plot the results.

\section{Immunocytofluorescence}

Cells were seeded in 8-well chamber slides (Fisher Scientific, UK) and cultured for 48 hours in a humidified atmosphere with $5 \% \mathrm{CO}_{2}$ at $37^{\circ} \mathrm{C}$. Serum-starvation was carried out for 24 hours. Cells were subsequently treated for another 24 hours, washed in PBS and fixed with 4\% paraformaldehyde for 10 minutes at room temperature. Cells were subsequently permeabilised in $0.4 \%$ Triton-X for 10 minutes and blocked in $3 \%$ bovine serum albumin (BSA), 5\% goat serum in PBS for 1 hour. Following three washes with PBS, 2 minutes each, cells were incubated with appropriate antibodies for two hours. The primary antibodies were washed off in PBS and cells incubated 
with 1:100 dilution of secondary antibodies, FITC- or PE-conjugated (Alexa Fluor 488 and Alexa Fluor 555, Invitrogen, UK) for another two hours. Again, three washes were performed and the side walls of the chambers carefully removed. Coverslips were mounted onto each slide using three drops of mounting medium containing 4,6-Diamidino-2-phenylindole (DAPI) which is a highly sensitive nucleic acid stain. Images were captured using confocal laser scanning microscopy Zeiss 700. Secondary antibody alone was used to correct for non-specific background.

\section{Migration study}

A549 cells were seeded in 96-well plates and allowed to form a confluent monolayer for 24 hours. Homogenous scratch wounds were introduced using a WoundMaker (Essen Bioscience, UK). The wound closure was monitored for up to 24 hours and data analysed using Incucyte Zoom Live Cell Imaging System (Essen Bioscience, UK). Two metric parameters were analysed: wound confluence, which reports the confluence of cells within the wound region, given as the percentage of the wound region area occupied by cells; and relative wound density, which relies on measuring the spatial cell density in the wound area relative to the spatial cell density outside of the wound area at a given time point.

\section{Statistical analysis}

All data in the figures are presented as mean values \pm SEM and all experiments have been repeated independently at least twice with 3-6 technical replicates. Statistical analysis was performed between two treatment groups by unpaired Student's t-test, and between multiple treatment groups by one-way analysis of variance (ANOVA) with Tukey post-hoc testing or two-way ANOVA with Bonferroni post-hoc test, using Graphpad Prism 5 software. The mean values of various parameters were considered to be significantly different when the $p$ value was calculated to be less than 0.05 .

\section{CONFLICTS OF INTEREST}

RCC has received research funding from GlaxoSmithKline and Novartis but has no competing interests to declare in terms of the work described in this article. GJ was a full time employee of Novartis Institutes for Biomedical Research during the study and has no competing interests to declare with respect to this work. CJS has received research funding from GSK and Boehringer Ingelheim, but has no competing interests to declare regarding the work in this manuscript.

\section{GRANT SUPPORT}

Medical Research Council UK (MRC) CASE studentship with Novartis awarded to RCC, MRC Centenary Award awarded to NS and RCC, and MRC Career Development Award G0800340 to CJS.

\section{Author contribution}

NS, AOS, MP, CJS, GJ and RCC conceived and designed the studies; NS, MP, VA and AOS performed experiments; EF, VC and SC synthesized in-house RWJ-58259 used in this study, NS, MP, AOS, CJS and RCC analyzed and interpreted the data; NS, MP and RCC drafted and edited the manuscript; RCC secured the grant funding. All authors reviewed the manuscript. Vanessa D'Antongiovanni's contribution to this work was supported by a short-term training fellowship from the European Respiratory Society (STRTF 2014-5569).

\section{REFERENCES}

1. Silvestri GA, Alberg AJ, Ravenel J. The changing epidemiology of lung cancer with a focus on screening. BMJ. 2009; 339: b3053-b3053. doi: 10.1136/bmj.b3053.

2. Dammacco F, Vacca A, Procaccio P, Ria R, Marech I, Racanelli V. Cancer-related coagulopathy (Trousseau's syndrome): review of the literature and experience of a single center of internal medicine. Clin Exp Med. 2013; 13 : 85-97. doi: 10.1007/s10238-013-0230-0.

3. Milsom C, Yu J, May L, Meehan B, Magnus N, Al-Nedawi K, Luyendyk J, Weitz J, Klement P, Broze G, Mackman $\mathrm{N}$, Rak J. The role of tumor-and host-related tissue factor pools in oncogene-driven tumor progression. Thromb Res. 2007; 120, Supplement 2: S82-91. doi: 10.1016/ S0049-3848(07)70135-4.

4. Schaffner F, Ruf W. Tissue factor and protease-activated receptor signaling in cancer. Semin Thromb Hemost. 2008; 34: 147-53. doi: 10.1055/s-2008-1079254.

5. Nierodzik ML, Karpatkin S. Thrombin induces tumor growth, metastasis, and angiogenesis: Evidence for a thrombin-regulated dormant tumor phenotype. Cancer Cell. 2006; 10: 355-62. doi: 10.1016/j.ccr.2006.10.002.

6. Chen J, Ishii M, Wang L, Ishii K, Coughlin SR. Thrombin receptor activation. Confirmation of the intramolecular tethered liganding hypothesis and discovery of an alternative intermolecular liganding mode. J Biol Chem. 1994; 269: 16041-5.

7. McCoy KL, Gyoneva S, Vellano CP, Smrcka AV, Traynelis SF, Hepler JR. Protease-activated receptor 1 (PAR1) coupling to $\mathrm{G}(\mathrm{q} / 11)$ but not to $\mathrm{G}(\mathrm{i} / \mathrm{o})$ or $\mathrm{G}(12 / 13)$ is mediated by discrete amino acids within the receptor second intracellular loop. Cell Signal. 2012; 24: 1351-60. doi: 10.1016/j.cellsig.2012.01.011. 
8. Fujimoto D, Hirono Y, Goi T, Katayama K, Matsukawa $\mathrm{S}$, Yamaguchi A. The activation of Proteinase-Activated Receptor-1 (PAR1) mediates gastric cancer cell proliferation and invasion. BMC Cancer. 2010; 10: 443. doi: 10.1186/1471-2407-10-443.

9. Wang F, Fisher J, Fishman DA. MMP-1-PAR1 axis mediates LPA-induced epithelial ovarian cancer (EOC) invasion. Gynecol Oncol. 2011; 120: 247-55. doi: 10.1016/j.ygyno.2010.10.032.

10. Chay CH, Cooper CR, Gendernalik JD, Dhanasekaran SM, Chinnaiyan AM, Rubin MA, Schmaier AH, Pienta KJ. A functional thrombin receptor (PAR1) is expressed on bonederived prostate cancer cell lines. Urology. 2002; 60: 760-5.

11. Tellez C, Bar-Eli M. Role and regulation of the thrombin receptor (PAR-1) in human melanoma. Oncogene. 2003; 22: 3130-7. doi: 10.1038/sj.onc.1206453.

12. Boire A, Covic L, Agarwal A, Jacques S, Sherifi S, Kuliopulos A. PAR1 is a matrix metalloprotease-1 receptor that promotes invasion and tumorigenesis of breast cancer cells. Cell. 2005; 120: 303-13. doi: 10.1016/j.cell.2004.12.018.

13. Darmoul D, Gratio V, Devaud H, Lehy T, Laburthe M. Aberrant expression and activation of the thrombin receptor protease-activated receptor-1 induces cell proliferation and motility in human colon cancer cells. Am J Pathol. 2003; 162: 1503-13. doi: 10.1016/S0002-9440(10)64283-6.

14. Nierodzik ML, Chen K, Takeshita K, Li JJ, Huang YQ, Feng XS, D'Andrea MR, Andrade-Gordon P, Karpatkin S. Protease-activated receptor 1 (PAR-1) is required and ratelimiting for thrombin-enhanced experimental pulmonary metastasis. Blood. 1998; 92: 3694-700.

15. Ghio P, Cappia S, Selvaggi G, Novello S, Lausi P, Zecchina G, Papotti M, Borasio P, Scagliotti GV. Prognostic role of protease-activated receptors 1 and 4 in resected stage IB non-small-cell lung cancer. Clin Lung Cancer. 2006; 7 : 395-400. doi: 10.3816/CLC.2006.n.023.

16. Melnikova VO, Balasubramanian K, Villares GJ, Dobroff AS, Zigler M, Wang H, Petersson F, Price JE, Schroit A, Prieto VG, Hung M-C, Bar-Eli M. Crosstalk between Proteaseactivated Receptor 1 and Platelet-activating Factor Receptor Regulates Melanoma Cell Adhesion Molecule (MCAM/ MUC18) Expression and Melanoma Metastasis. J Biol Chem. 2009; 284: 28845-55. doi: 10.1074/jbc.M109.042150.

17. Arora P, Cuevas BD, Russo A, Johnson GL, Trejo J. Persistent transactivation of EGFR and ErbB2/HER2 by protease-activated receptor-1 promotes breast carcinoma cell invasion. Oncogene. 2008; 27: 4434-45. doi: 10.1038/ onc.2008.84.

18. Massagué J. TGFbeta in Cancer. Cell. 2008; 134: 215-30. doi: 10.1016/j.cell.2008.07.001.

19. Jenkins RG, Su X, Su G, Scotton CJ, Camerer E, Laurent GJ, Davis GE, Chambers RC, Matthay MA, Sheppard D. Ligation of protease-activated receptor 1 enhances alpha(v) beta6 integrin-dependent TGF-beta activation and promotes acute lung injury. J Clin Invest. 2006; 116: 1606-14. doi: 10.1172/JCI27183.
20. Akhurst RJ, Hata A. Targeting the TGF $\beta$ signalling pathway in disease. Nat Rev Drug Discov. 2012; 11: 790-811. doi: $10.1038 / \mathrm{nrd} 3810$.

21. Scotton CJ, Krupiczojc MA, Königshoff M, Mercer PF, Lee YCG, Kaminski N, Morser J, Post JM, Maher TM, Nicholson AG, Moffatt JD, Laurent GJ, Derian CK, et al. Increased local expression of coagulation factor $\mathrm{X}$ contributes to the fibrotic response in human and murine lung injury. J Clin Invest. 2009; 119: 2550-63. doi: 10.1172/JCI33288.

22. Shi M, Zhu J, Wang R, Chen X, Mi L, Walz T, Springer TA. Latent TGF- $\beta$ structure and activation. Nature. 2011; 474: 343-9. doi: 10.1038/nature10152.

23. Hinz B. The extracellular matrix and transforming growth factor- $\beta 1$ : Tale of a strained relationship. Matrix Biol J Int Soc Matrix Biol. 2015; 47: 54-65. doi: 10.1016/j. matbio.2015.05.006.

24. López-Novoa JM, Nieto MA. Inflammation and EMT: an alliance towards organ fibrosis and cancer progression. EMBO Mol Med. 2009; 1: 303-14. doi: 10.1002/ emmm.200900043.

25. Nagaraj NS, Datta PK. Targeting the transforming growth factor-beta signaling pathway in human cancer. Expert Opin Investig Drugs. 2010; 19: 77-91. doi: $10.1517 / 13543780903382609$.

26. Wells JE, Howlett M, Cole CH, Kees UR. Deregulated expression of connective tissue growth factor (CTGF/ CCN2) is linked to poor outcome in human cancer. Int J Cancer J Int Cancer. 2015; 137: 504-11. doi: 10.1002/ ijc. 28972

27. Pardali K, Moustakas A. Actions of TGF-beta as tumor suppressor and pro-metastatic factor in human cancer. Biochim Biophys Acta. 2007; 1775: 21-62. doi: 10.1016/j. bbcan.2006.06.004.

28. Van Aarsen LAK, Leone DR, Ho S, Dolinski BM, McCoon PE, LePage DJ, Kelly R, Heaney G, Rayhorn P, Reid C, Simon KJ, Horan GS, Tao N, et al. Antibodymediated blockade of integrin alpha $\mathrm{v}$ beta 6 inhibits tumor progression in vivo by a transforming growth factor-betaregulated mechanism. Cancer Res. 2008; 68: 561-70. doi: 10.1158/0008-5472.CAN-07-2307.

29. Córdova G, Rochard A, Riquelme-Guzmán C, Cofré C, Scherman D, Bigey P, Brandan E. SMAD3 and SP1/SP3 Transcription Factors Collaborate to Regulate Connective Tissue Growth Factor Gene Expression in Myoblasts in Response to Transforming Growth Factor $\beta$. J Cell Biochem. 2015; 116: 1880-7. doi: 10.1002/jcb.25143.

30. Vizcaíno C, Mansilla S, Portugal J. Sp1 transcription factor: A long-standing target in cancer chemotherapy. Pharmacol Ther. 2015; 152: 111-24. doi: 10.1016/j. pharmthera.2015.05.008.

31. Nierodzik ML, Kajumo F, Karpatkin S. Effect of thrombin treatment of tumor cells on adhesion of tumor cells to platelets in vitro and tumor metastasis in vivo. Cancer Res. 1992; 52: 3267-72. 
32. Fischer EG, Ruf W, Mueller BM. Tissue factor-initiated thrombin generation activates the signaling thrombin receptor on malignant melanoma cells. Cancer Res. 1995; 55: 1629-32.

33. Even-Ram S, Uziely B, Cohen P, Grisaru-Granovsky S, Maoz M, Ginzburg Y, Reich R, Vlodavsky I, Bar-Shavit $\mathrm{R}$. Thrombin receptor overexpression in malignant and physiological invasion processes. Nat Med. 1998; 4: 909-14.

34. Even-Ram SC, Maoz M, Pokroy E, Reich R, Katz B-Z, Gutwein P, Altevogt P, Bar-Shavit R. Tumor Cell Invasion Is Promoted by Activation of Protease Activated Receptor-1 in Cooperation with the $\alpha v \beta 5$ Integrin. J Biol Chem. 2001; 276: 10952-62. doi: 10.1074/jbc.M007027200.

35. Zain J, Huang YQ, Feng X, Nierodzik ML, Li JJ, Karpatkin S. Concentration-dependent dual effect of thrombin on impaired growth/apoptosis or mitogenesis in tumor cells. Blood. 2000; 95: 3133-8.

36. Zhang Y, Handley D, Kaplan T, Yu H, Bais AS, Richards T, Pandit KV, Zeng Q, Benos PV, Friedman N, Eickelberg O, Kaminski N. High throughput determination of TGF $\beta 1 /$ SMAD3 targets in A549 lung epithelial cells. PloS One. 2011; 6: e20319. doi: 10.1371/journal.pone.0020319.

37. Massagué J, Gomis RR. The logic of TGFbeta signaling. FEBS Lett. 2006; 580: 2811-20. doi: 10.1016/j. febslet.2006.04.033.

38. Franchini M, Mannucci PM. Thrombin and cancer: from molecular basis to therapeutic implications. Semin Thromb Hemost. 2012; 38: 95-101. doi: 10.1055/s-0031-1300955.

39. Ferguson BW, Gao X, Zelazowski MJ, Lee J, Jeter CR, Abba MC, Aldaz CM. The cancer gene WWOX behaves as an inhibitor of SMAD3 transcriptional activity via direct binding. BMC Cancer. 2013; 13: 593. doi: 10.1186/1471-2407-13-593.

40. Zhang YE. Non-Smad pathways in TGF-beta signaling. Cell Res. 2009; 19: 128-39. doi: 10.1038/cr.2008.328.

41. Davies M, Robinson M, Smith E, Huntley S, Prime S, Paterson I. Induction of an epithelial to mesenchymal transition in human immortal and malignant keratinocytes by TGF-beta1 involves MAPK, Smad and AP-1 signalling pathways. J Cell Biochem. 2005; 95: 918-31. doi: 10.1002/ jcb.20458.

42. Zavadil J, Bitzer M, Liang D, Yang YC, Massimi A, Kneitz S, Piek E, Bottinger EP. Genetic programs of epithelial cell plasticity directed by transforming growth factor-beta. Proc Natl Acad Sci U S A. 2001; 98: 6686-91. doi: 10.1073/ pnas. 111614398 .

43. Kasai H, Allen JT, Mason RM, Kamimura T, Zhang Z. TGF-beta1 induces human alveolar epithelial to mesenchymal cell transition (EMT). Respir Res. 2005; 6: 56. doi: 10.1186/1465-9921-6-56.

44. Deng X, Mercer PF, Scotton CJ, Gilchrist A, Chambers RC. Thrombin induces fibroblast CCL2/JE production and release via coupling of PAR1 to Galphaq and cooperation between ERK1/2 and Rho kinase signaling pathways. Mol Biol Cell. 2008; 19: 2520-33. doi: 10.1091/mbc.E07-07-0720.
45. Ortiz-Stern A, Deng X, Smoktunowicz N, Mercer PF, Chambers RC. PAR-1-dependent and PAR-independent pro-inflammatory signaling in human lung fibroblasts exposed to thrombin. J Cell Physiol. 2012; 227: 3575-84. doi: $10.1002 /$ jcp. 24061 .

46. Otsuki T, Fujimoto D, Hirono Y, Goi T, Yamaguchi A. Thrombin conducts epithelial-mesenchymal transition via protease-activated receptor-1 in human gastric cancer. Int J Oncol. 2014; 45: 2287-94. doi: 10.3892/ijo.2014.2651.

47. Song JS, Kang CM, Park CK, Yoon HK. Thrombin induces epithelial-mesenchymal transition via PAR-1, PKC, and ERK1/2 pathways in A549 cells. Exp Lung Res. 2013; 39: 336-48. doi: 10.3109/01902148.2013.820809.

48. Schmidt VA, Vitale E, Bahou WF. Genomic cloning and characterization of the human thrombin receptor gene. Structural similarity to the proteinase activated receptor-2 gene. J Biol Chem. 1996; 271: 9307-12.

49. Tellez C, McCarty M, Ruiz M, Bar-Eli M. Loss of activator protein-2alpha results in overexpression of proteaseactivated receptor-1 and correlates with the malignant phenotype of human melanoma. J Biol Chem. 2003; 278: 46632-42. doi: 10.1074/jbc.M309159200.

50. Derynck R, Zhang YE. Smad-dependent and Smadindependent pathways in TGF-beta family signalling. Nature. 2003; 425: 577-84. doi: 10.1038/nature02006.

51. Blume SW, Snyder RC, Ray R, Thomas S, Koller CA, Miller DM. Mithramycin inhibits SP1 binding and selectively inhibits transcriptional activity of the dihydrofolate reductase gene in vitro and in vivo. J Clin Invest. 1991; 88: 1613-21. doi: 10.1172/JCI115474.

52. Fajardo OA, Thompson K, Parapuram SK, Liu S, Leask A. Mithramycin reduces expression of fibro-proliferative mRNAs in human gingival fibroblasts. Cell Prolif. 2011; 44: 166-73. doi: 10.1111/j.1365-2184.2011.00738.x.

53. Kong L-M, Liao C-G, Fei F, Guo X, Xing J-L, Chen $\mathrm{Z}-\mathrm{N}$. Transcription factor $\mathrm{Sp} 1$ regulates expression of cancer-associated molecule CD147 in human lung cancer. Cancer Sci. 2010; 101: 1463-70. doi: 10.1111/j.1349-7006.2010.01554.x.

54. Rao M, Atay SM, Shukla V, Hong Y, Upham T, Ripley RT, Hong JA, Zhang M, Reardon E, Fetsch P, Miettinen M, Li X, Peer CJ, et al. Mithramycin Depletes Specificity Protein 1 and Activates p53 to Mediate Senescence and Apoptosis of Malignant Pleural Mesothelioma Cells. Clin Cancer Res. 2016; 22: 1197-210. doi: 10.1158/1078-0432. CCR-14-3379.

55. Sleiman SF, Langley BC, Basso M, Berlin J, Xia L, Payappilly JB, Kharel MK, Guo H, Marsh JL, Thompson LM, Mahishi L, Ahuja P, MacLellan WR, et al. Mithramycin is a gene-selective $\mathrm{Sp} 1$ inhibitor that identifies a biological intersection between cancer and neurodegeneration. J Neurosci Off J Soc Neurosci. 2011; 31: 6858-70. doi: 10.1523/JNEUROSCI.0710-11.2011.

56. Choi E-S, Nam J-S, Jung J-Y, Cho N-P, Cho S-D. Modulation of specificity protein 1 by mithramycin $\mathrm{A}$ as 
a novel therapeutic strategy for cervical cancer. Sci Rep. 2014; 4: 7162. doi: 10.1038/srep07162.

57. Mansilla S, Portugal J. Sp1 transcription factor as a target for anthracyclines: Effects on gene transcription. Biochimie. 2008; 90: 976-87. doi: 10.1016/j.biochi.2007.12.008.

58. Mansilla S, Priebe W, Portugal J. Sp1-Targeted Inhibition of Gene Transcription by WP631 in Transfected Lymphocytes. Biochemistry (Mosc). 2004; 43: 7584-92. doi: 10.1021/ bi036185e.

59. Mamuya FA, Duncan MK. aV integrins and TGF- $\beta$-induced EMT: a circle of regulation. J Cell Mol Med. 2012; 16: 445-55. doi: 10.1111/j.1582-4934.2011.01419.x.

60. Giampieri S, Manning C, Hooper S, Jones L, Hill CS, Sahai E. Localized and reversible TGFbeta signalling switches breast cancer cells from cohesive to single cell motility. Nat Cell Biol. 2009; 11: 1287-96. doi: 10.1038/ncb1973.
61. Poole RM, Elkinson S. Vorapaxar: first global approval. Drugs. 2014; 74: 1153-63. doi: 10.1007/s40265-014-0252-2.

62. John AE, Luckett JC, Tatler AL, Awais RO, Desai A, Habgood A, Ludbrook S, Blanchard AD, Perkins AC, Jenkins RG, Marshall JF. Preclinical SPECT/CT imaging of $\alpha v \beta 6$ integrins for molecular stratification of idiopathic pulmonary fibrosis. J Nucl Med Off Publ Soc Nucl Med. 2013; 54: 2146-52. doi: 10.2967/jnumed.113.120592.

63. Soto AG, Trejo J. N-linked glycosylation of proteaseactivated receptor-1 second extracellular loop: a critical determinant for ligand-induced receptor activation and internalization. J Biol Chem. 2010; 285: 18781-93. doi: 10.1074/jbc.M110.111088. 